19. «Альтернативні методи підтримання психосоматичного здоров'я», 2020 - https://www.facebook.com/groups/691374335046543

20. «Клінічна психологія». Курсанти-психологи, третій курс, 2020. https://www.facebook.com/groups/288651000811635

21. «Психодіагностика», третій курс, соціальна педагогіка, 2020. https://www.facebook.com/groups/790563511690921

22. Психолого-педагогічна громадськість України та домашні улюбленці, 2020.- https://www.facebook.com/groups/282344725944301

23. «Медична психологія», третій курс медики, Інститут Біології та Медицини, КНУ Тараса Шевченка, 2020. https://www.facebook.com/groups/2271955993097037

24. «Medical Psychology», third year medical foreign students, Institute of Biology and Medicine, KNU named after Taras Schevchenko.https://www.facebook.com/groups/522233258413026

25. Безпека психосоматичного здоров'я молоді в Інтернеті, 2021. https://www.facebook.com/groups/471083360933240

26. Група прихильників оздоровчо-тренувального плавання факультету психології КНУ імені Тараса Шевченка, 2019 https://www.facebook.com/groups/358897828025722/

DOI https://doi.org/10.30525/978-9934-26-114-5-50

\title{
СПОСОБИ ВДОСКОНАЛЕННЯ КОМУНІКАТИВНОЇ КОМПЕТЕНТНОСТІ ВИКЛАДАЧА ЗВО
}

\author{
Кучерова О. О. \\ кандидат філологічних наук,
}

доиент кафедри англійської мови факультету гуманітарних наук

Національний університет «Києво-Могилянська академія»

Нестеренко Л. О.

кандидат наук з державного управління, доцент,

дочент кафедри англійської мови факультету гуманітарних наук

Національний університет «Києво-Могилянська академія»

м. Київ, Украӥна

Аналіз наукових праць $[1,3,4,7,8]$ свідчить, що комунікативна компетентність викладача ВНЗ - це інтегральний показник, що характеризує якість розвиненості складних комунікативних навичок та здатність особистості викладача адаптуватися до нових суспільних 
реалій у відповідності до вимог, що $є$ характерними для системи освіти. Відтак, навички комунікативної компетентності та шляхи іiі вдосконалення стають важливим стратегічним ресурсом, відсутність якого призводить до суттєвих втрат в освітньому процесі.

Підтвердженням даної тези $€$ Новий професійний стандарт викладачів вищої освіти [6]. В професійному стандарті на групу професій «Викладачі закладів вищої освіти», затвердженому 23 березня 2021 року визначено, що комунікативна компетентність та здатність проявляти емпатію (пункт 4, ЗК.03) є важливими характеристиками загальної професійної компетентності викладача вищого навчального закладу. При цьому беззаперечною $є$ теза про те, що якість інших компетентностей, визначених у Професійному стандарті, (Здатність мотивувати людей та рухатися до нової мети (ЗК.09), Здатність проявляти толерантність та повагу до культурної різноманітності (ЗК.11), Здатність діяти соціально відповідально та свідомо (ЗК.12)), значною мірою детерміновані рівнем сформованості саме комунікативної компетентності.

В той же час сучасні педагоги $[1,3]$ та психологи $[2,4]$ засвідчують, що стан та якісні характеристики комунікативної компетентності викладача ВНЗ значною мірою залежать і від його особистісних характеристик: системи цінностей, психологічної культури, самосвідомості, соціально-перцептивного інтелекту тощо. Тому поряд iз світоглядною та професійною підготовкою особливого значення у процесі вдосконалення комунікативної компетентності, набуває i особистісна підготовка викладача в системі вищої освіти. Адже іiі метою є формування в структурі особистості викладача ВНЗ професійно значущих якостей особистості, пї гуманістичної спрямованості, психологічної культури, здатності до професійної ідентифікації.

Саме тому, використання особистісного підходу може стати провідним методологічним інструментарієм у ході вдосконалення комунікативної компетентності викладача ВН3. Адже його основу становлять сукупність вихідних концептуальних уявлень, цільових установок, методик психодіагностичних і психолого-технологічних засобів, які забезпечують більш глибоке, цілісне розуміння пізнання особистості суб'єкта освітньої діяльності та його розвиток.

В даному контексті корисними можуть стати ідеї Д.Філіпса [7], який у своїх працях акцентує увагу на людино-центричних підходах до навчання дорослих. Він зазначає, що надзвичайно важливим стає трансформаційне навчання («transformational learning»), яке поєднує у собі всі сучасні досягнення педагогічної й психологічної наук, i синонімами якого є нетравматичне навчання («non-traumatic learning») i 
нейробіологічне навчання («neurobiological learning»). В той же час, Стівен Вінсент [8] розвиваючи наукові позиції Д.Філіпса, обгрунтовує важливість емпатійного ставлення й цінування іншої особистості. Адже саме гуманістичні якості й характеристики визначають позитивний та здоровий розвиток викладача ВНЗ. Автори [2, 3, 7, 8], аналізуючи традиційні й новітні підходи до педагогічної науки, наголошують на важливості трансперсональної психології, етичних аспектах освітньої та педагогічної діяльності, впровадженні новітніх психологічних досягнень в педагогічну практику, які активно доповнятимуть зміст гуманістичних підходів до освіти. Аналіз праць науковців $[1,3,4,7,8]$ доводить, що основними компонентами розвитку комунікативної компетентності учасників освітніх взаємодій в системі вищої освіти, мають бути творчість, саморозвиток, етика, моральність, увага до інших, рефлексія, тощо.

Беззаперечним виглядає висновок про те, що, одним із пріоритетних завдань вдосконалення комунікативної компетентності викладачів ВНЗ мають стати розвиток відповідальності, рефлексії та створення умов для постійного саморозвитку, впровадження гуманістичних цінностей.

Відтак, створення профілю комунікативної компетентності викладача ВНЗ може суттєво посприяти вдосконаленню комунікативної компетентності учасників освітнього процесу. Адже в даному профілі можуть бути окреслені основні характеристики високого (задовільного) рівня комунікативної компетентності викладача ВНЗ. Ключовими ж характеристиками даного профілю можуть стати комунікативність, зворотній зв'язок, здатність до саморозвитку, відповідальність, рефлексія, тощо.

Ще одним елементом вдосконалення комунікативної компетентності викладачів ВНЗ може стати впровадження тренінгових програм до системи освіти та підвищення кваліфікації викладачів ВНЗ. За допомогою тренінгових програм можливий швидкий розвиток зворотного зв'язку (feedback), який визначається як один із основних компонентів комунікативної компетентності викладача ВНЗ. Також впровадження тренінгових програм допоможе максимально ефективно впливати на інші компоненти професійної компетентності викладача BН3, а саме:

- інтелектуальний (компетентність, аналітичність мислення);

- особливості нервової системи (сила і лабільність нервових процесів в розумово-мовній діяльності, працездатність, стійкість до стресів, емоційна стійкість, комунікативність);

- особистісний (активність, ділова спрямованість, мотивація, вміння приймати правильні рішення). 
Відтак, завданнями системи освіти в цілому та самоосвіти зокрема, у частині розвитку та вдосконалення комунікативної компетентності викладачів ВНЗ можуть стати:

- створення профілю комунікативної компетентності викладача BH3;

- впровадження в систему підготовки, перепідготовки та підвищення кваліфікації науково-педагогічних працівників тренінгових підходів, спрямованих на розвиток їх комунікативної компетентності. Такі тренінгові підходи є важливими як засіб формування установок на конкретну взаємодію у процесі потенційно складної викладацької діяльності. У процесі таких занять буде відбуватися більш активне формування навичок психодіагностики, антиципації, організації та оптимізації колективної взаємодії, установок на співпрацю. Тобто тих компонентів діяльності, які безпосередньо впливають на формування комунікативної компетентності. При цьому основними завданнями тренінгових програм можуть стати:

- підготовка викладачів ВНЗ як кваліфікованих користувачів психологічних знань;

- формування у викладачів ВНЗ навичок оцінювання психологічних особливостей особистості, оволодіння психотехніками ефективної комунікації;

- розвиток вольових якостей, навичок саморегуляції, тощо.

Таким чином, розроблення профілю комунікативної компетентності викладача ВНЗ та впровадження тренінгових підходів до розвитку та вдосконалення комунікативної компетентності науково-педагогічних працівників суттєво вдосконалять комунікативні навички викладачів зокрема, та якість надання освітніх послуг в цілому. Адже дані способи забезпечать реалізацію ефективних способів розвитку комунікативної компетентності викладачів ВН3 через формування продуктивної особистісної позиції по відношенню до себе та активного пошуку вирішення нових завдань, які поставатимуть перед ними у процесі здійснення професійної діяльності в системі вищої освіти.

\section{Література:}

1. Бодалева А. А. Психологічне спілкування. Москва: Изд-во Інститут практичної психології, Воронеж: Н.П.О, Модек, 1996. 256 с.

2. Єзова С. А. Комунікативна компетенція. Наукові та технічні бібліотеки. 2008. № 4. С. 100-107.

3. Жуков Ю. М. Петровська Л. А., Растянников П. В. Діагностика та розвиток компетентності в спілкуванні. Москва, 1991. 96 с. 
4. Москаленко В. В. Соціальна психологія. Підручник. Видання 2-ге, виправлене та доповнене. К. : Центр учбової літератури, $2008.688 \mathrm{c}$.

5. Нестеренко Л. О. Особливості використання психологічних тренінгів у процесі викладання іноземної мови за професійним спрямуванням. Актуальні проблеми державного управління, педагогіки та психологї: збірник наукових праць Херсонського національного технічного університету. Херсон: Грінь Д. С., 2014, Вип. 1 (10). C. $107-110$.

6. Професійний стандарт на групу професій «Викладачі закладів вищої освіти», затверджений 23 березня 2023 року. URL: https://mon.gov.ua/storage/app/media/pto/standarty/2021/03/25/Standart\%20na\%20hrupu\%20profesiy_Vykladachi\%20zakladiv\%20vyshchoyi\% 20osvity_25.03.pdf (дата звернення 12.07.2021).

7. Phillips J. Handbook of Training Evaluation and Measurement Methods. - Gulf Publishing Company, Texas, 1990. 213 p.

8. Vincent S. Being Empathic: a Companion for Counselors and Therapists. NY.: Radcliffe Publishing, 2005. 244 p.

DOI https://doi.org/10.30525/978-9934-26-114-5-51

\title{
ВИКОРИСТАННЯ ПРОСКТНИХ ТЕХНОЛОГІЙ У ФОРМУВАННІ ПІДПРИСМНИЦЬКОЇ КОМПЕТЕНТНОСТІ МАЙБУТНІХ ШЕВ-ДИЗАЙНЕРІВ
}

\author{
Кушнір В. В. \\ аспірант \\ Інститут професійно-технічної освіти \\ Національної академії педагогічних наук України \\ м. Київ, Україна
}

Стратегічною метою сучасної освіти $є$ формування високоосвіченої, інтелігентної, самодостатньої творчої особистості 3 інноваційним типом мислення і діяльності, здатної гідно відповісти на виклики сьогодення. Сучасні соціально-економічні умови і конкуренція на ринку праці зумовлюють необхідність володіння майбутніми дизайнерами основ підприємницької діяльності. Особливо ця проблема актуальна для умов євроінтеграції та глобалізації господарських процесів в Україні, де зростає соціально-економічна важливість під- 